\section{International Scientific Journal Theoretical \& Applied Science}

p-ISSN: 2308-4944 (print) e-ISSN: 2409-0085 (online)

Year: $2017 \quad$ Issue: $11 \quad$ Volume: 55

Published: 24.11.2017 http://T-Science.org
Kymyzai Ahmatovna Dehkanova candidate of juridical science assistant professor of department of theory of law and government of Osh state university of Kyrgyz Republic

SECTION 32. Jurisprudence.

\title{
ABOUT LEGAL NATURE OF THE SYSTEM OF PROTECTION AND PROTECTION OF HUMAN AND CIVIL RIGHTS AND FREEDOMS
}

Abstract: This article examines the legal nature of such major related categories as "protection of law" and "protection of law" in law and in the theory of legal science.

Key words: human and civil rights and freedoms, the protection of human rights, the protection of human and civil rights and freedoms.

Language: Russian

Citation: Dehkanova KA (2017) ABOUT LEGAL NATURE OF THE SYSTEM OF PROTECTION AND PROTECTION OF HUMAN AND CIVIL RIGHTS AND FREEDOMS. ISJ Theoretical \& Applied Science, 11 (55): 171-174.

Soi: http://s-o-i.org/1.1/TAS-11-55-20 Doi: crossef https://dx.doi.org/10.15863/TAS.2017.11.55.20

\section{О ПРАВОВОЙ ПРИРОДЕ СИСТЕМЫ ОХРАНЫ И ЗАЩИТЫ ПРАВ И СВОБОД ЧЕЛОВЕКА И ГРАЖДАНИНА}

Аннотация: В данной статье рассматривается правовая природа таких основных смежных категорий, как "охрана права" и "зашита права" в законодательстве и в теории правовой науки.

Ключевые слова: права и свободы человека и гражданина, защита прав человека, обеспечение прав и свобод человека и гражданина.

\section{Introduction}

Общепризнано, что право направлено на выполнение двух основных функций: регулятивной и охранительной. Охранительная функция права и в правовой науке и в законодательстве определяется через такие смежные категории, как «охрана прав» и «защита прав», «обеспечение прав».

К сожалению, приходится констатировать, что единой точки зрения среди ученых и законодателей по разграничению этих близких, но не тождественных понятий в настоящее время не существует. Эти термины употребляются подчас произвольно, без учета лексического значения, что недопустимо в законотворчестве.

В научной литературе термины «охрана», «защита» и «обеспечение» особенно широко и обстоятельно получили различное толкование в советской юридической науке, в связи с чем возникает необходимость уточнения их содержания.

\section{Materials and Methods}

Следует согласиться с мнением, что понятие «обеспечение» является родовым по отношению к понятиям «охрана» и «защита». Оно включает в себя всю систему политических, экономических, социальных, духовных, правовых и иных мер и условий, направленных на наиболее полное пользование личностью социальных благ.

Понятия «охрана» и «защита» рассматриваются либо как тождественные $[1$, с. 18], либо «защита» понимается как более узкий термин, по сравнению с понятием «охрана», либо каждое из них наделяется самостоятельным содержанием.

В связи с этим, анализ юридической литературы позволяет заключить, что существует несколько научных точек зрения, подчас противоположных и взаимоисключающих и не имеющих единого подхода к определению защиты прав человека.

Попытаемся выделить несколько научных направлений, выявить преимущества и слабые стороны каждого и определить собственную 
позицию в решении непростой общетеоретической задачи.

В разграничении понятий «охрана права» и «защита права» существует три основных подхода.

Так, казахский ученый С.Н. Сабикенов, конкретизируя цель защиты прав человека, дефинирует «защиту прав человека» как «осуществляемую в установленном законом порядке правоприменительную деятельность органов государства, обусловленную нарушением либо оспариванием этих прав, цель которой состоит в восстановлении или подтверждении этих прав» [2, с. 62].

О.В. Иванов понимает под «защитой прав человека» «совершение юрисдикционным органом государства определенных властных действий, направленных на обеспечение управомоченному лицу возможности реализации принадлежащего ему права и на принуждение обязанных лиц к совершению определенных действий в пользу управомоченного» [3, с. 15].

В.П. Волжанин под «защитой прав» подразумевает реализацию субъективного права независимо от воли обязанного лица в установленном законом порядке [4, с. 81], т.е. в данном случае, под защитой понимается вся правоохранительная деятельность.

Полагаем, что наиболее приемлемой из всех точек зрения юристов, примыкающих к этой группе, является точка зрения Н.С. Малеина, который под «защитой прав» понимает систему средств, направленных на предупреждение правонарушений и устранение их последствий $[5$, c. 192]. Н.С. Малеин все же различает охрану и защиту прав: охрана прав - более широкое понятие, включающее все юридические правила по поводу определенного блага, а под защитой права он понимает меры, предусмотренные в законе в тех случаях, когда право уже нарушено.

По мнению С. Н. Кожевникова, «охрана» это установление общего правового режима, а «защита» - те меры, которые предпринимаются в случаях, когда права нарушены или оспорены [6, c. 4-5].

По С.С. Алексееву «защита права» рассматривается как государственнопринудительная деятельность, направленная на осуществление «восстановительных» задач - на восстановление нарушенного права, обеспечение юридической обязанности [7, с. 193].

Другой подход к определению этих понятий сводится к тому, что охрана прав включает в себя довольно обширный спектр правовых явлений.

Так, Л.О. Красавчикова пишет: «...по своей структуре охрана дифференцируется на три следующих звена: регулятивное, обеспечительное и защитное...».
Наконец, существует еще одно мнение по вопросу об определении понятия «охрана прав». Оно было сформулировано В. Д. Ардашкиным. Исследователь полагает, что охрана прав является государственным принуждением, которое включает в себя следующие конструкции: институт ответственности, институт защиты, институт предупреждения и институт процессуального обеспечения.

Ученый К. К. Гасанов полагает, что авторы, придерживающиеся того же мнения, что и Н. В. Витрук, В. К. Бабаев, М. Н. Малеина, Л. О. Красавчикова, «безосновательно ограничили механизм охраны прав только принуждением, исключив из него многие важные непринудительные правовые средства охраны прав, что противоречит мнению многих ученых».

Следует согласиться с точкой зрения А. В.Стремоухова, предлагающего в качестве критерия дифференцирования данных понятий определять их функциональное назначение. По его мнению, охрана есть тогда, когда нет нарушения права, а защита должна наступать тогда, когда есть правонарушение.

Вместе с тем, следует отметить, что существующая точка зрения Н.В. Витрука отождествляет понятия «защита прав» и «охрана прав», обозначив их взаимозаменяемость.

Правовую охрану отождествляют с защитой и некоторые другие авторы. Отметим общее в позициях этих ученых. Они полагают, что охрана прав и защита прав - идентичные понятия, существующие в рамках правоохранительных отношений.

Однако, если В.А. Тархов допускает существование охраны и защиты прав при наличии угрозы нарушения прав, т.е. расширяет содержание понятия «защита прав», то С.C. Алексеев понимает охрану и защиту прав как восстановительную деятельность, сужая содержание понятия «охрана прав». В качестве доказательства своей позиции, эти ученые указывают на отрасли публичного права.

Созвучно этому мнению и мнение Н.И. Матузова, который отмечает: «Вообще охрана и защита субъективного права или охраняемого законом интереса - не одно и то же: охраняются они постоянно, а защищаются только тогда, когда нарушаются. Защита есть момент охраны, одна из ее форм. Эти понятия не совпадают».

В то же время другая группа ученых, наоборот, считает более широким понятие «охрана права».

В широком и узком смысле охрану прав предлагает различать А.П. Сергеев. В широком смысле, по его мнению, охрана права включает в себя меры не только правового, но и экономического, политического, организационного и иного характера, 
направленные на создание необходимых условий для осуществления субъективных прав. В узком смысле «охрана» включает лишь предусмотренные законом меры, направленные на восстановление или признание прав и на защиту в случае их нарушения или оспаривания. Таким образом, защита в понимании ученого является охраной в узком смысле слова.

Особую группу, пожалуй, составляют те исследователи, которые вообще отрицают целесообразность использования какого-либо термина.

Например, Б. Шубина считает, что термин «охрана права» не имеет юридического значения и практически не применяется в законодательстве, иначе говоря, правовое регулирование тех или иных общественных отношений, закрепление в правовых нормах тех или иных прав носит общерегулятивный, а не правоохранительный характер. Эти исследователи подтверждают свою точку зрения, апеллируя к трудовому законодательству, где одним из основных направлений государственной политики в области охраны труда является защита законных интересов работников.

В противовес подходу Б.Шубиной, В.А. Тархов полагает, что охрана каждого права существует постоянно и имеет целью обеспечить его осуществление, не допустить его нарушение.

В нормативно-правовой оборот термин «правовая защита» вошел после принятия Конституции СССР от 1977 г. Так, ст. 36 Конституции соответственно провозглашала равные права женщины и мужчины и правовую защиту материнства и детства. Далее «правовая защита» находила свое отражение во многих нормативно-правовых актах.

Во многих нормативно-правовых актах предусмотрена презумпция охраны и защиты прав человека. Примером может служить Кодекс об административной ответственности Кыргызской Республики.

Так, в частности, задачами законодательства об административных правонарушениях являются защита личности, охрана прав и свобод человека и гражданина, охрана здоровья граждан. Однако перечисленные законодательные установки не в полной мере определяют правовую защиту.

Таким образом, если государство в своем основном законе закрепило право, значит, оно берет на себя ответственность за его обеспечение. Следовательно, основная задача правового регулирования прав и свобод человека состоит в том, чтобы их признать, предоставить гарантии соблюдения и обеспечить их защиту.

$$
\text { Гражданский кодекс Кыргызской }
$$

Республики, устанавливая неприкосновенность частной собственности (охранительная норма благо), закрепил не только право собственника владеть, пользоваться и распоряжаться принадлежащим ему имуществом (регулятивная норма), но и способы ее защиты [8].

По нашему мнению, более верна позиция, в соответствии с которой под охраной понимаются взаимосвязанные меры, осуществляемые государственными органами и общественными организациям, направленные на предупреждение нарушений прав, на устранение их причин и способствующие нормальному процессу реализации личностью своих прав и свобод.

Защита же предполагает принудительный способ осуществления права, применяемый в установленном законом порядке компетентными органами в целях восстановления нарушенного права. Именно на стадии защиты нарушение должно быть ликвидировано, а право восстановлено [9, с. 68]. Для государства как организации публичной власти именно защита прав является одной из основных функций.

Итак, наличие различных мнений ученых о соотношении понятий «защита права» и «охрана права» показывает, что большинство исследователей под защитой права подразумевает меры, направленные на восстановление нарушенного права или на предотвращение угрозы нарушения прав и законных интересов. Вместе с тем, известны точки зрения и тех ученых, которые отдают предпочтение понятию «защита права», ставя от него в зависимость понятие «охрана права».

Таким образом, уяснение содержания понятий «охрана права» и «защита права» позволит решить еще одну важную общетеоретическую задачу - определить содержание понятия «юридические средства», совокупность которых и даст возможность эффективно осуществлять и государственную, и судебную, и в целом правовую защиту и охрану субъективных прав.

Если цель механизма охраны основных прав состоит в предупреждении и профилактике нарушений прав человека, в устранении препятствй (не являющихся правонарушениями), мешающих их осуществлению, то цель механизма защиты прав заключается в том, чтобы восстановить уже нарушенное право, если это объективно возможно.

Следовательно, отличительным признаком механизмов охраны прав и защиты прав является степень их связи с нарушением прав. Охрана есть тогда, когда нет правонарушения, защита должна наступать тогда, когда есть нарушение основных прав. Такой точки зрения придерживаются многие авторы. В юридической литературе 
продолжаются дискуссии по определению содержания понятия «системы защиты прав».

По этому поводу рассматривается система защиты прав личности в узком смысле как функционирование конкретных государственных органов, приоритетной задачей которых является защита прав личности, и в широком смысле в качестве сложной универсальной системы государственно-правовых институтов, средств, действий, направленных на пресечение нарушений прав и свобод человека и гражданина, их восстановление или соразмерную компетенцию, которые обеспечивают условия свободного развития индивида и общества $[10$, с. 117].

Другой исследователь В. А. Лебедев считает, что система защиты прав человека включает в себя целостную совокупность элементов: формы (самозащита, государственная и общественная защита); способы (способы, применяемые соответствующими субъектами для защиты прав и свобод) и средства (в зависимости от правомочий субъектов различных форм) защиты прав и свобод человека и гражданина [11, c. 75].

\section{Conclusion}

Дискуссии исследователей по определению правовой природы понятий «охрана права» и «защита права» разрешает еще одну значимую теоретико-правовую задачу - выявить сущность понятия «юридические средства». Совокупность указанных юридических средств позволит эффективно реализовать государственную, судебную, правовую защиту и охрану субъективных прав граждан в целом.

\section{References:}

1. (1972) Konstitutsionnyye prava i svobody sovetskikh grazhdan. [Tekst] / Pod red. L.D.Voyevodina. -M., 1972. - 212 p.

2. Sabikenov S.N. (1974) Nekotoryye voprosy zashchity sub"yektivnykh prav i okhranyayemykh zakonom interesov sovetskikh grazhdan [Tekst] / S.N. Sabikenov // Problemy gosudarstva i prava: sb. tr. nauch.sotr. i aspir. M., 1974. -Vyp. 9.- p. 62-67.

3. Ivanov O.V. (1996) Zashchita sub"yektivnykh prav $\mathrm{i}$ problema istiny $\mathrm{v}$ grazhdanskom protsesse [Tekst] / O. V. Ivanov // Vestnik MGU. Ser. 11. Pravo. -1996. -№ 2. -p. 15-18.

4. Volzhanin V.P. (1971) Formy zashchity sub"yektivnykh grazhdanskikh prav // Pravovedeniye. 1971. -№ 6. -p. 81-99.

5. Malein N.S. (1981) Grazhdanskiy zakon i prava lichnosti v SSSR [Tekst] / N.S. Malein. - M., 1981. $-312 \mathrm{p}$.

6. Kozhevnikova S.N. (1968) Mera zashchity v sovetskom prave [Tekst] / S. N. Kozhevnikova: avtoref. dis. ... kand. yurid.nauk. -Sverdlovsk, 1968. $-25 \mathrm{p}$.

7. Alekseyev S.S. (1981) Obshchaya teoriya prava [Tekst] / S.S. Alekseyev.-M.: «Yuridicheskaya literatura», 1981-T. 1.-336 p.

8. (1996) Grazhdanskiy kodeks Kyrgyzskoy Respubliki. Chast' I ot 8 maya 1996 goda № 15. - Available: http://www.toktom.kg (Accessed: 10.11.2017).

9. Papichev N.V. (2002) Zashchita prav cheloveka i problema metoda pravovogo regulirovaniya: Dis. kand. yurid. nauk. Volgograd. 2002. -251 p.

10. Sorokin V.V. (2000) Gosudarstvo perekhodnogo perioda: teoreticheskiye voprosy. Monografiya. Barnaul: AAEP, 2000. -190 p.

11. Lebedev V.A. (2015) Konstitutsionnyye prava $i$ svobody cheloveka i grazhdanina v sovremennoy Rossii: kontseptsiya, ogranicheniya, mekhanizm okhrany i zashchity. Monografiya, OOO «Prospekt», 2015. 